\title{
Opioidergic regulation of gonadotrophin secretion in the early prepubertal bull calf
}

\author{
A. C. O. Evans, W. D. Currie ${ }^{*}$ and N. C. Rawlings \\ Veterinary Physiological Sciences, Western College of Veterinary Medicine, University of \\ Saskatchewan, Saskatoon, Saskatchewan, S7N OWO, Canada
}

\begin{abstract}
The control of gonadotrophin secretion during the early developmental period in the bull is poorly understood; opioidergic regulation may be involved. The opioid antagonist naloxone was administered to bull calves (i.v. $n=5 ; 1 \mathrm{mg} \mathrm{kg}^{-1}$ body weight $\mathrm{h}^{-1}$ ) for $12 \mathrm{~h}$ at 4,12 , 18,24 and 32 weeks of age. Control animals $(n=5)$ received sterile saline solution. During the treatment period, $4 \mathrm{ml}$ blood samples were collected every $12 \mathrm{~min}$. The calves were also weighed and blood samples collected every two weeks from 2 to 48 weeks of age. Scrotal circumference was measured from 20 to 48 weeks of age to determine age at puberty. Serum samples were assayed for concentrations of $\mathrm{LH}, \mathrm{FSH}$, testosterone and oestradiol. On the basis of blood samples taken every two weeks, serum concentrations of $\mathrm{LH}$ increased to a peak at six weeks of age and then decreased; serum concentrations of FSH reached a peak at 20 weeks of age. Serum concentrations of testosterone and oestradiol increased with scrotal circumference from 20 to 48 weeks of age. On the basis of blood samples taken every $12 \mathrm{~min}$ for $12 \mathrm{~h}$, we concluded that the early rise in serum LH concentrations was due to an increase in LH pulse frequency. LH pulse amplitude decreased from 4 to 18 weeks of age and FSH pulse amplitude from 4 to 32 weeks of age. Naloxone treatment increased LH pulse frequency at 4 and 24 weeks of age but not at 12,18 or 32 weeks of age. LH pulse amplitude was depressed and mean serum concentrations of LH were increased by naloxone at 4 weeks of age. At 12 weeks of age, LH pulse amplitude and mean and basal serum LH concentrations were increased by naloxone. At 18 weeks, only mean concentrations of LH were increased by naloxone. The only effect of naloxone on FSH secretion was to increase FSH pulse amplitude at 24 weeks of age. We conclude that there is opioidergic inhibition of LH secretion in the young bull calf, but that between 12 and 18 weeks of age a decrease in opioidergic inhibition on LH pulse frequency contributes to the overall increase in mean circulating concentrations of $\mathrm{LH}$ at this time.
\end{abstract}

\section{Introduction}

Puberty has been defined as the phase of bodily development during which the gonads secrete hormones in amounts that cause accelerated growth of the genital organs and the appearance of secondary sexual characteristics (Donovan and van der Werff ten Bosch, 1965). Puberty has been considered to be the discrete developmental age when reproduction is possible (Killian and Amann, 1972; Barber and Almquist, 1975). Hence, the period before puberty is a period of sexual maturation in which gonadal development, bodily development and endocrine development take place. In the heifer, puberty is simply first ovulation; in the bull it is defined as the age at which an ejaculate contains $50 \times 10^{6}$ spermatozoa with a minimum motility of $10 \%$ (Wolf et al., 1965). Regardless of breed, body weight and age, puberty has been correlated with a scrotal circumference of $27.9 \pm 0.2 \mathrm{~cm}$ in bulls (Lunstra et al., 1978).

*Present address: Department of Health Sciences, East Tennessee State University, Johnson City, TN 37614-0002, USA.

Received 30 July 1992.
The prepubertal pattern of circulating gonadotrophins in the bull calf has been established. In the immediate postnatal period, circulating concentrations of $\mathrm{LH}$ are low, and this gives way to an early transient rise in $\mathrm{LH}$ from about 10 until 20 weeks of age (Rawlings et al., 1978; McCarthy et al., 1979; Amann et al., 1986). At about 24 weeks of age, LH concentrations start to increase to puberty (Rawlings et al., 1972; Rawlings et al., 1978; Schams et al., 1981). Circulating concentrations of FSH show a similar pattern, except the early rise appears to last longer and the increase to puberty occurs earlier (Schams et al., 1981). Serum testosterone concentrations are initially very low but start to increase at about 15-20 weeks of age and rise to puberty and on into early adulthood (Rawlings et al., 1972; Secchiari et al., 1976; Lunstra et al., 1978; Rawlings et al., 1978; Rawlings and Cook, 1986). In the young bull calf, when testosterone secretion is low, serum concentrations of androstenedione and some $5 \alpha$-reduced androgens are high (Rawlings et al., 1972; Abdel Malak Bedair and Thibier, 1979; Rawlings and Cook, 1986). Significant quantities of serum oestradiol and oestradiol receptors in the hypothalamus and median eminence 
have been measured in very young bull calves, with an indication that circulating oestradiol concentrations reach a maximum at six weeks of age and are low thereafter (Amann et al., 1986).

The exact mechanisms controlling sexual maturation in bulls are not understood. It would appear that control is at the level of the hypothalamus, since the pituitary in very young bulls is responsive to exogenous $\mathrm{GnRH}$ when gonadotrophin secretion is otherwise low (Lacroix and Pelletier, 1979; Schams et al., 1981; Rodriguez and Wise, 1989) and the testes produce pulses of testosterone in response to endogenous pulses of $\mathrm{LH}$ (Karg et al., 1976; Schams et al., 1978).

The involvement of opioid peptides in regulating the onset of puberty in various species has been considered (Wilkinson and Landymore, 1989; Barb et al., 1991). In rats, precocious puberty has been induced in females by the early administration of the opioid receptor antagonist naloxone (Sirinathsinghii et al., 1985). In the intact male rat, it was concluded that naloxone had no effect on gonadotrophin secretion until the peripubertal period, when testosterone secretion was increasing (Schulz et al., 1982; Bhanot and Wilkinson, 1983; Cicero et al., 1986). It has been suggested that the presence of gonadal steroids may be important for opioidergic control of gonadotrophin secretion (Limonta et al., 1987). In contrast to this, it appears that opioidergic control over $\mathrm{LH}$ secretion in ram lambs occurs early when testosterone concentrations are low, is subsequently diminished and then re-established close to puberty (Rawlings et al., 1991). MacDonald et al. (1990) studied opioidergic regulation of $\mathrm{LH}$ secretion in Holstein bull calves from 3 to 21 weeks of age. Separate groups of animals received a single bolus infusion of the opioid receptor antagonist naloxone at intervals of two to four weeks and its effects on mean circulating $\mathrm{LH}$ concentrations were observed over $2 \mathrm{~h}$. They concluded that, except at the onset of the early rise in LH secretion, endogenous opioids inhibited LH secretion up to 21 weeks of age. The aim of our study was to establish the degree of opioidergic control over pulsatile $\mathrm{LH}$ and FSH secretion during the early prepubertal period and particularly to document the role of opioids in the regulation of the early transient rise in gonadotrophin secretion in the beef bull calf.

\section{Materials and Methods}

\section{Animals}

Ten age matched ( \pm 5 days), spring-born, Hereford bull calves were maintained in a beef management system; calves were nursed at pasture until weaning at 21 weeks of age, from which time they were maintained in a paddock and were fed a ration of $21 \%$ ground barley, $51 \%$ ground hay, $22 \%$ ground straw, $0.005 \%$ of a $1: 1$ calcium:phosphorus mineral mix $(w / w)$ ad libitum, with brome alfalfa hay and water freely available. Once every two weeks, from 2 to 48 weeks of age, each calf was weighed and a single blood sample collected by jugular venepuncture. Scrotal circumference was also measured once every two weeks from 20 to 48 weeks of age (Hahn et al., 1969).

\section{Naloxone treatments}

The ten calves were randomly assigned to either naloxone treatment or saline control groups. At 4, 12, 18, 24 and 32 weeks of age the calves received hourly i.v. injections of naloxone in saline $\left(n=5: 1 \mathrm{mg} \mathrm{kg}^{-1}\right.$ body weight $\mathrm{h}^{-1}$; Research Biomedicals Inc., Natick, MA) or physiological saline solution $(n=5)$ for $12 \mathrm{~h}$. The calves were fitted with jugular catheters (vinyl tubing SV-70; internal and external diameters $1.0 \mathrm{~mm}$ and $1.5 \mathrm{~mm}$, respectively; Dural Plastics \& Engineering, Dural, NSW, Australia) $18 \mathrm{~h}$ before treatment. Throughout the $12 \mathrm{~h}$ infusion period, $4 \mathrm{ml}$ blood samples were collected every $12 \mathrm{~min}$. During infusion periods, calves were housed loose in pens and were free to nurse their dams which were tied in stalls. Weaned calves were cannulated in a similar way and housed unrestrained. All blood samples were allowed to clot at room temperature for $12-18 \mathrm{~h}$; the clots were removed and after centrifugation at $1500 \mathrm{~g}$ for $20 \mathrm{~min}$, the serum was poured off and stored at $-20^{\circ} \mathrm{C}$ until assayed.

\section{Radioimmunoassays}

FSH and LH. Serum concentrations of FSH and LH were determined in double antibody radioimmunoassays (Rawlings $e t$ al., 1984). For the FSH assay, the first antibody used was NIDDK-anti-oFSH-1, and FSH concentrations are expressed in terms of USDA-bFSH-I1. The range of the standard curve was $0.2-16 \mathrm{ng} \mathrm{ml}^{-1}$. The sensitivity of the assay was $0.2 \mathrm{ng} \mathrm{ml}^{-1}$ (defined as the lowest concentration of unlabelled FSH capable of displacing iodinated FSH from the first antibody; $P<0.05$, by Students $t$ test). Intra- and interassay coefficients of variation (CVs) were 9.1 and $14.0 \%$ (mean $=3.10 \mathrm{ng} \mathrm{ml}^{-1}$ serum) and 9.1 and $16.7 \%$ (mean $=1.69 \mathrm{ng} \mathrm{ml}^{-1}$ serum), respectively. $\mathrm{LH}$ concentrations are expressed in terms of NIDDK-bLH4. The range of the standard curve was $0.1-8.0 \mathrm{ng} \mathrm{ml}^{-1}$. The sensitivity of the assay was $0.1 \mathrm{ng} \mathrm{ml}^{-1}$. Intra- and interassay CVs were 12.3 and $18.7 \%$ (mean $=2.90 \mathrm{ng} \mathrm{ml}^{-1}$ serum) and 11.2 and $18.6 \%$ (mean $=0.71 \mathrm{ng} \mathrm{ml}^{-1}$ serum), respectively.

Testosterone and oestradiol. Serum testosterone and oestradiol concentrations were measured by radioimmunoassay (Cook et al., 1982; Joseph et al., 1992, respectively). The range of the testosterone standard curve was $0.03-5.00 \mathrm{ng} \mathrm{ml}^{-1}$ and the sensitivity was $0.03 \mathrm{ng} \mathrm{ml}^{-1}$. The intra- and interassay CVs were 9 and $15 \%$ (mean $=2.14 \mathrm{ng} \mathrm{ml}^{-1}$ serum) and 9 and $12 \%$ (mean $=1.25 \mathrm{ng} \mathrm{ml}^{-1}$ serum), respectively. The range of the oestradiol standard curve was $1-100 \mathrm{pg} \mathrm{ml}^{-1}$ and the assay sensitivity was $1 \mathrm{pg}$ oestradiol $\mathrm{ml}^{-1}$ serum. The intra- and interassay $\mathrm{CVs}$ were 14 and $19 \%$ (mean $=13.2 \mathrm{pg} \mathrm{ml}^{-1}$ serum) and 14 and $15 \%$, respectively (mean $=6.7 \mathrm{pg} \mathrm{ml}^{-1}$ serum).

\section{Statistical analysis}

The episodic patterns of circulating LH and FSH in blood samples collected every $12 \mathrm{~min}$ for $12 \mathrm{~h}$ were determined using PC-Pulsar (J. Gitzen and V. Ramirez, University of Illinois) and are expressed in terms of mean and basal circulating concentrations, pulse amplitude and pulse frequency. Pulses were identified using standard deviation criteria (Merriam and Wachter, 1982) and basal concentrations were determined by subtraction of the pulses from the $12 \mathrm{~h}$ gonadotrophin profile.

For the periods of intensive collection of blood samples, comparison of the gonadotrophin data between control and 
naloxone-treated heifers at each age was done by repeated measures ANOVA on the Statistical Analysis System (SAS Version 6, SAS Institute Inc., Cary, NC). Student-NewmanKeuls (SNK) test for least significant difference $(P<0.05)$ was used as the post ANOVA test. The patterns of mean serum concentrations of FSH, LH, testosterone and oestradiol, in blood samples taken every two weeks, were analysed using repeated measures ANOVA (True Epistat ${ }^{\circledR}$ : Epistat Services, Richardson, Texas) and SNK $(P<0.05)$. The linear regression correlation between testosterone and oestradiol was also done using True Epistat ${ }^{\circledR}$. All the data are presented as means \pm SEM.

\section{Results}

The mean ( \pm SEM) birth weight of bull calves was $42.0 \pm 1.6 \mathrm{~kg}$ and the mean age at puberty, as determined by a scrotal circumference of $28 \mathrm{~cm}$ (Lunstra et al., 1978), was $37.7 \pm 0.7$ weeks of age (ranging between 34.6 and 42.6 weeks), at a body weight of $293.1 \pm 7.0 \mathrm{~kg}$. Mean growth rate between birth and 40 weeks of age was $7.1 \pm 0.2 \mathrm{~kg}^{\text {week }}{ }^{-1}$. Naloxone treatments had no effect on the age at puberty $(P>0.05)$.

Repeated measures ANOVA of the annual profiles of the serum concentrations of $\mathrm{LH}, \mathrm{FSH}$, testosterone and oestradiol in blood samples taken every two weeks (Fig. 1) all showed a significant effect of age $(P<0.0002)$. The serum LH concentrations at six weeks of age were higher $(P<0.05)$ than $52 \%$ of the remaining points and the serum FSH concentrations at 20 weeks were higher $(P<0.05)$ than $83 \%$ of the remaining points. Serum concentrations of both testosterone and oestradiol showed a significant increase with age $(P<0.0001)$. Testosterone concentrations from 40 to 48 weeks of age (inclusive) were greater than at all other ages $(P<0.01)$ and similarly for oestradiol, concentrations between 40 and 48 weeks were greater than at $89 \%$ of the remaining sampling times $(P<0.05)$. The linear regression coefficient between testosterone and oestradiol was $0.915(P<0.0001)$.

In blood samples taken every $12 \mathrm{~min}$ for $12 \mathrm{~h}$ from the control animals (Fig. 2), mean serum LH concentrations and LH pulse frequency were higher at 12 and 18 weeks than at 4,24 and 32 weeks of age $(P<0.05)$. LH pulse amplitude decreased from 4 to 18 weeks of age $(P<0.05)$ but basal serum LH concentrations did not change between periods of collection of blood samples $(P>0.05)$. The only effect of age on the pulsatile secretion of FSH in the control animals was that FSH pulse amplitude (Fig. 3) decreased from 4 to 32 weeks of age $(P<0.05)$.

Naloxone treatments increased mean serum concentrations of LH $(P<0.05)$ and LH pulse frequency $(P<0.01)$ and decreased LH pulse amplitude $(P<0.05)$ at four weeks of age (Figs 2 and 4). At 12 weeks of age naloxone increased mean and basal concentrations of LH $(P<0.01)$ and LH pulse amplitude $(P<0.05)$, but had no effect on pulse frequency $(P>0.05)$. At 18 weeks of age naloxone significantly increased only mean serum concentrations of $\mathrm{LH}(P<0.01)$; the apparent effect on basal concentrations of $\mathrm{LH}$ only approached significance $(P=0.07)$. At 24 weeks, naloxone increased LH pulse frequency $(P<0.01)$, and at 32 weeks naloxone had no significant effect on the pulsatile secretion of LH $(P>0.05)$, but did tend
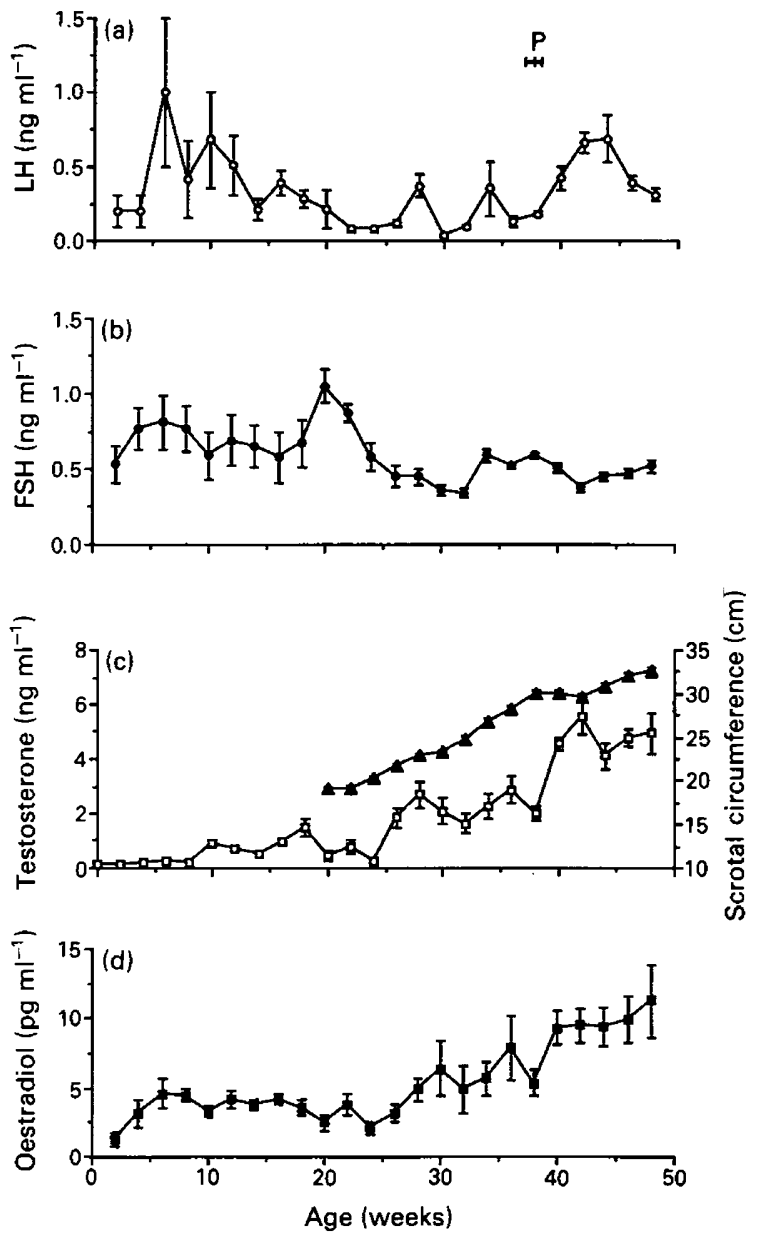

Fig. 1. Mean ( \pm SEM) serum concentrations of (a) LH, (b) FSH, (c) testosterone and scrotal circumference and (d) oestradiol for Hereford bulls from which blood samples were collected every two weeks from 2 to 48 weeks of age $(n=10) . P=$ puberty at $37.0 \pm 0.7$ weeks.

to increase $\mathrm{LH}$ pulse frequency $(P=0.06)$. The only significant effect of naloxone on the pulsatile secretion of FSH was to increase $\mathrm{FSH}$ pulse frequency at 24 weeks of age $(P<0.05$; Fig. 3). However, naloxone tended to decrease FSH pulse amplitude at 18 weeks of age $(P=0.09)$ and to increase it at 24 weeks of age $(P=0.08)$.

\section{Discussion}

On the basis of samples collected every other week, a transient rise in circulating gonadotrophin concentrations was seen in the early prepubertal period, in agreement with previous observations (Rawlings et al., 1978; Schams et al., 1981). Data from intensive bleedings showed that the increase in mean serum $\mathrm{LH}$ concentrations, between 6 and 20 weeks of age, was caused by an increase in LH pulse frequency, despite a decrease in LH pulse amplitude. An increase in LH pulse frequency at this time has been noted previously (McCarthy et al., 1979; Amann and Walker, 1983). A similar trend was seen in FSH data from blood samples collected every two weeks and every $12 \mathrm{~min}$ for $12 \mathrm{~h}$ at 

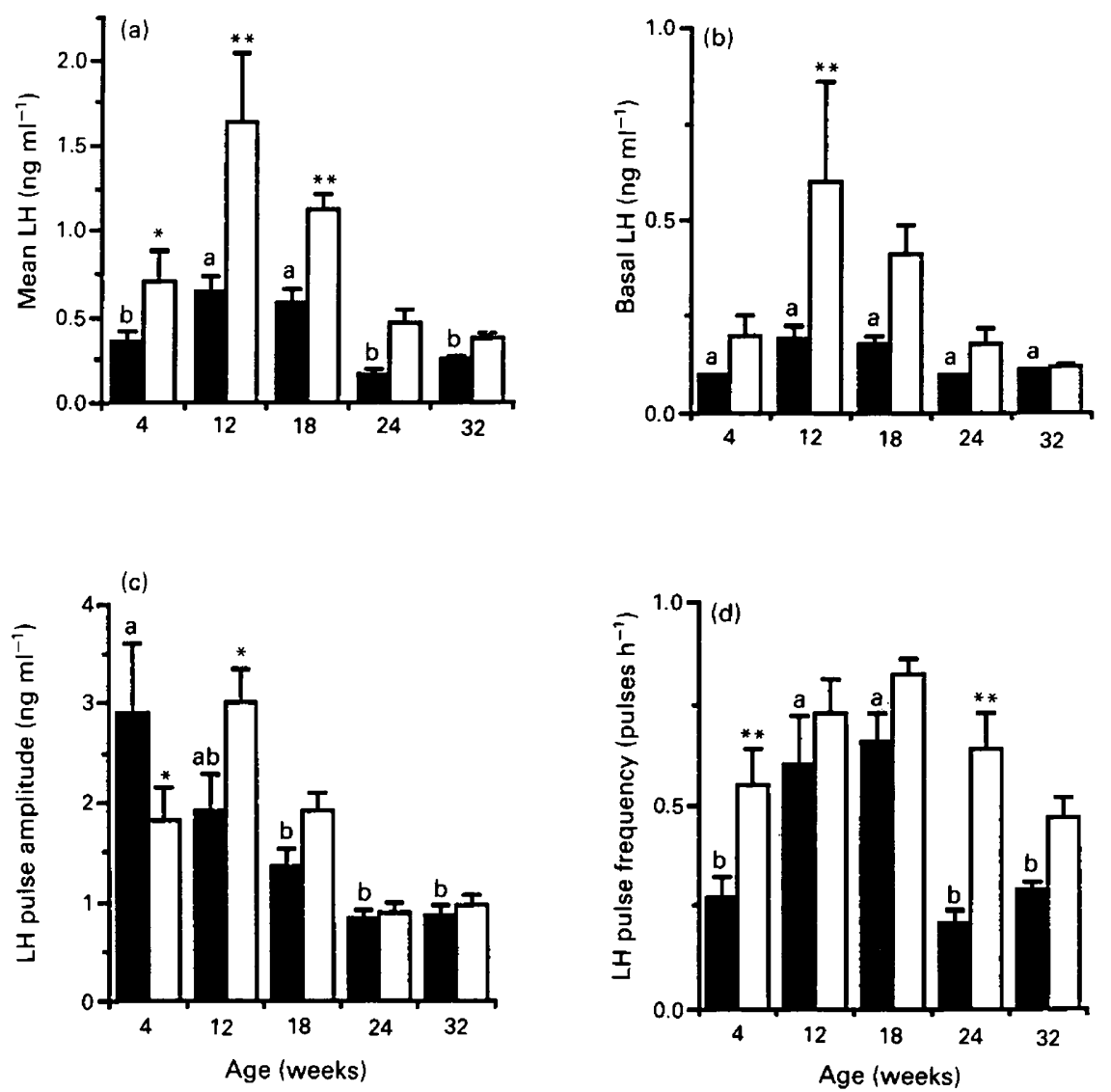

Fig. 2. (a) Mean, (b) basal serum LH concentrations, (c) LH pulse amplitude and (d) frequency (mean \pm SEM) in bulls treated with naloxone ( []$; n=5 ; 1 \mathrm{mg} \mathrm{kg}^{-1}$ body weight $\mathrm{h}^{-\mathrm{I}}$ ) or saline $(\square ; n=5$ ) for $12 \mathrm{~h}$ at $4,12,18,24$ and 32 weeks of age; blood samples were taken every $12 \mathrm{~min}$ for $12 \mathrm{~h}$. Differences between treatment and control groups at an age are shown by ${ }^{*} P<0.05$ and ${ }^{* *} P<0.01$. Control groups with different superscripts are significantly different from each other $(P<0.05)$.

$4,12,18,24$ and 32 weeks of age. It appeared that the mean peak serum concentrations of FSH at 20 weeks of age was too transient to be well reflected in blood samples taken frequently at 18 and 24 weeks of age. The short-lived increase in circulating $\mathrm{LH}$ and FSH concentrations between 6 and 20 weeks of age are assumed to be important for the initiation of testicular growth and differentiation (McCarthy et al., 1979; Amann and Walker, 1983). During this early period of development, androstenedione and $5 \alpha$-reduced androgens are secreted as well as low levels of testosterone (Rawlings et al., 1972; Abdel Malek Bedair and Thibier, 1979; Rawlings and Cook, 1986). Differentiated Sertoli cells and Leydig cells first appear after 20 weeks of age (Curtis and Amann, 1981) and serum testosterone concentrations start to increase at about 15-20 weeks of age (Rawlings et al., 1978; McCarthy et al., 1979).

The temporal pattern of serum oestradiol concentrations reflected testosterone concentrations in a linear fashion in bull calves during the study reported here. This suggested a similar site and stimulus for production and secretion of both steroids. The relative roles of oestradiol and testosterone as negative feedback agents on gonadotrophin secretion in the bull calf are unclear; both oestradiol and testosterone have potent inhibitory effects on pulsatile LH secretion in bull calves (Schanbacher,
1984), castrated bulls (Schanbacher et al., 1983; Kennedy and Rawlings, 1984) and in castrated rams (D'Occhio et al., 1983). In a previous study, serum concentrations of oestradiol rose in the young bull calf only to fall before the early rise in gonadotrophin secretion (Amann et al., 1986). An increase in serum concentrations of oestradiol from two to six weeks of age was seen in the study reported here but no subsequent decline was observed.

Our data showed that in the four-week-old bull calf there was opioidergic inhibition of LH pulse frequency. Naloxone treatment at this age increased LH pulse frequency and caused a decrease in pulse amplitude. This inverse relationship between frequency and amplitude demonstrated the limited LH content of the pituitary at this time (Amann et al., 1986). The removal of opioidergic inhibition over LH pulse frequency between 4 and 12 weeks of age may have allowed the early rise in $\mathrm{LH}$ secretion to occur. During this time, no further increase in $\mathrm{LH}$ pulse frequency could be stimulated with naloxone. At between 18 and 24 weeks of age opioidergic inhibition of LH pulse frequency was re-established and mean serum concentrations of $\mathrm{LH}$ were decreased. It therefore appeared that the early transient rise in circulating LH concentrations between 6 and 20 weeks of age was at least contributed to by a temporary removal of opioidergic suppression on LH pulse frequency. 

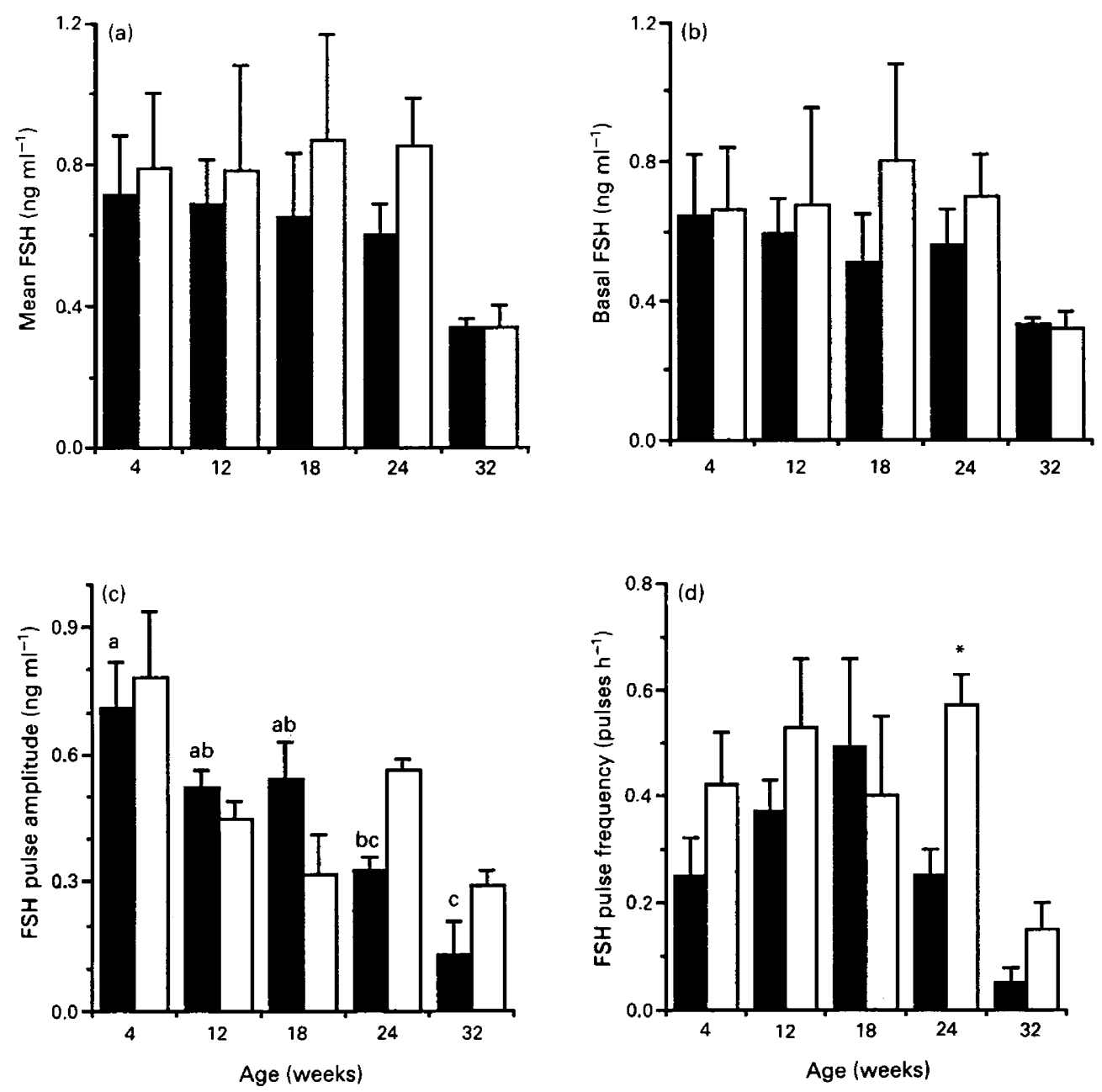

Fig. 3. (a) Mean and (b) basal serum FSH concentrations and (c) FSH pulse amplitude and (d) frequency (mean \pm SEM) in bulls treated with naloxone $\left(\square ; n=5 ; 1 \mathrm{mg} \mathrm{kg}^{-1}\right.$ body weight $\mathrm{h}^{-1}$ ) or saline $(\square ; n=5)$ for $12 \mathrm{~h}$ at $4,12,18,24$ and 32 weeks of age; blood samples were taken every $12 \mathrm{~min}$ for $12 \mathrm{~h}$. Differences between treatment and control groups at an age are shown by ${ }^{*} P<0.05$. Control groups with different superscripts are significantly different from each other $(P<0.05)$.

MacDonald et al. (1990) suggested that opioidergic suppression of mean serum concentrations of LH in Holstein bull calves was absent during the onset of the early prepubertal increase in LH secretion. In their study, treatments consisted of a single bolus injection of naloxone preceded and followed by $2 \mathrm{~h}$ of blood sampling. Their study did not extend beyond 21 weeks of age and LH secretion was characterized only in terms of mean serum concentrations. LH pulse frequency at these ages is about one pulse in $2 \mathrm{~h}$ or less, and it is known that a challenge with naloxone produces an instant $\mathrm{LH}$ pulse in many situations (Currie and Rawlings, 1989). Long periods of naloxone treatment are therefore preferable to determine opioidergic influences on gonadotrophin secretion.

In our study the only parameter of pulsatile LH secretion that appeared to escape opioidergic suppression during the early rise in LH secretion was LH pulse frequency. During this time opioidergic systems suppressed LH pulse amplitude and basal serum concentrations of $\mathrm{LH}$; presumably a fall in opioidergic suppression of LH pulse frequency between 4 and 12 weeks of age caused an increase in pulse frequency which contributed to the increase in mean serum LH concentrations (McCarthy et al., 1979; Amann and Walker, 1983). Our data also indicated that, despite a lack of opioidergic suppression of mean and basal serum LH concentrations and LH pulse amplitude at 24 and 32 weeks of age, opioidergic suppression of LH pulse frequency could have at least partially explained the drop in mean serum LH concentrations at that time. However, other mechanisms such as enhanced steroid negative feedback must also be important (Schanbacher, 1984).

Prepubertal heifers show a similar early rise in gonadotrophin secretion to bulls (Schams et al., 1981; Evans et al., 1992). In heifers the rise is due to an increase in pulse amplitude. Significant opioidergic inhibition of gonadotrophin secretion occurs only at 4 months of age in heifers (Evans et al., 1992). The argument for a role of endogenous opioids in the early rise in LH secretion in heifers did not appear to be as strong as in the bulls in this study.

Opioidergic control of FSH secretion in the bull calf appeared to be much less than that for $\mathrm{LH}$; the only significant effects of naloxone were seen after the early rise in FSH secretion, in the 

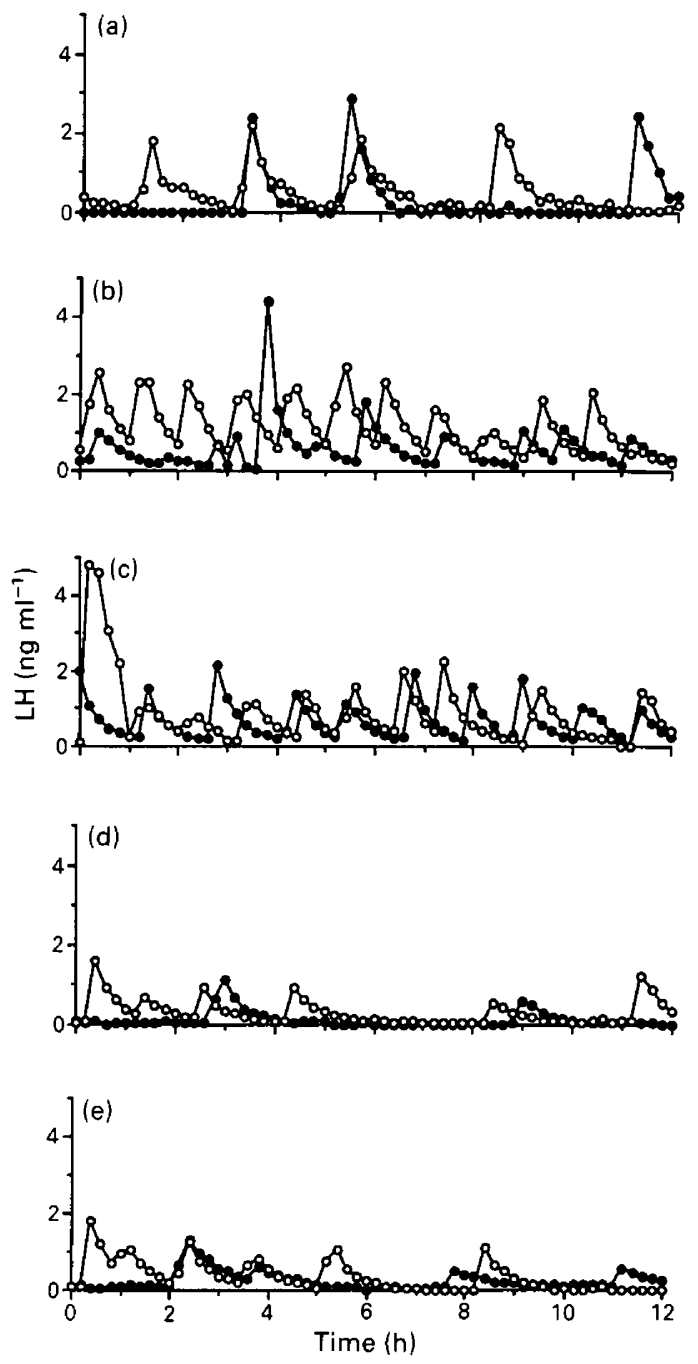

Fig. 4. The temporal pattern of circulating concentrations of serum LH in a control calf ( ; saline) and a naloxone-treated calf $\left(0 ; 1 \mathrm{mg} \mathrm{kg}^{-1}\right.$ body weight $\mathrm{h}^{-1}$ on the h) at (a) 4, (b) 12 , (c) 18 , (d) 24 and (e) 32 weeks of age. Blood samples were collected every $12 \mathrm{~min}$ for $12 \mathrm{~h}$.

form of an increase in pulse frequency at 24 weeks of age. Since opioidergic regulation of the pituitary secretion of gonadotrophins occurs via $\mathrm{GnRH}$ at the level of the hypothalamus (Blank and Roberts, 1982), the differential response of LH and FSH to naloxone treatments may be due to unequal pituitary stores of the gonadotrophins or differential pituitary secretory patterns, both of which may alter with age. Naloxone has little effect on the pattern of circulating $\mathrm{FSH}$ in prepubertal heifers (Evans et al., 1992), mature ewes (Currie and Rawlings, 1989), ewe lambs (Rawlings and Churchill, 1990) or ram lambs (Rawlings et al., 1991). This is in complete contrast to four- to five-week-old male pigs in which i.p. injection of naloxone stimulates FSH but not LH secretion (Trudeau et al., 1990).

In ram lambs opioidergic suppression of $\mathrm{LH}$ pulse amplitude occurs only at an early age (5-10 weeks) and is then absent until puberty at 34 weeks of age (Rawlings et al., 1991). In the mature ram it was suggested that pulsatile LH secretion is regulated by endogenous opioids (Schanbacher, 1985) and that opioids mediate steroid negative feedback suppression of LH secretion. Seasonal changes in opioidergic regulation of $\mathrm{LH}$ secretion may occur, indicating that opioids may mediate environmental factors at the level of the hypothalamus (Ebling and Lincoln, 1985). The exact pathways by which opioidergic systems regulate hypothalamic activity are unclear.

Data presented here do not support the idea that opioid pathways convey only steroid negative feedback messages. At 4 and 24 weeks of age, when circulating testosterone concentrations were low, naloxone increased gonadotrophin secretion. At 32 weeks of age when scrotal circumference and testosterone concentrations were increasing, naloxone had no significant effects. This situation may be analogous to the ram lamb in which opioidergic regulation of $\mathrm{LH}$ secretion occurred early on when testosterone concentrations were low (steroid independent) and was then absent until puberty, when LH secretion was suppressed by opioids but in the presence of high serum testosterone concentrations (steroid dependent) (Rawlings et al., 1991). Unfortunately, the bull calves in the present study were not challenged with naloxone around the time of puberty. Naloxone has been shown to increase LH secretion in steers (Peck et al., 1988) and to increase LH pulse frequency in castrated and intact rams (Schanbacher, 1985). Hence, opioidergic regulation of LH secretion may have steroid dependent and steroid independent components in prepubertal bulls and rams.

In conclusion we have shown that between 6 and 20 weeks of age there are increased circulating concentrations of LH and FSH in the bull calf and that the removal and subsequent re-establishment of opioidergic inhibition on LH pulse frequency may contribute to the early rise and fall in serum LH concentrations.

The authors thank S. J. Cook for technical assistance, B. Kerr and his staff for the care and management of the animals and NIDDK and USDA for the provision of reagents for the gonadotrophin assays. This research was funded by the Natural Sciences and Engineering Research Council of Canada.

\section{References}

Abdel Malak Bedair G and Thibier M (1979) Peripheral plasma androstenedione and testosterone concentrations in bulls before and during puberty Journal of Reproduction and Fertility 56 7-10

Amann RP and Walker OA (1983) Changes in the pituitary-gonadal axis associated with puberty in Holstein bulls Journal of Animal Science $\mathbf{5 7}$ 433-442

Amann RP, Wise ME, Glass JD and Nett TM (1986) Prepubertal changes in the hypothalamic pituitary axis of Holstein bulls Biology of Reproduction 34 $7 \mathrm{I}-8 \mathrm{I}$

Barb CR, Kraeling RR and Rampacek GB (1991) Opioid modulation of gonadotropin and prolactin secretion in domestic farm animals Domestic Animal Endocrinology 8 15-27

Barber KA and Almquist JO (1975) Growth and feed efficiency and their relationship to pubertal traits of Charolais bulls Journal of Animal Science $\mathbf{4 0}$ 288-301

Bhanot R and Wilkinson M (1983) Opioidergic control of gonadotropin secretion during puberty in the rat: a neurochemical basis for the hypothalamic 'gonadostat' Endocrinology 113 596-603

Blank MS and Roberts DL (1982) Antagonist of gonadotropin-releasing hormone blocks naloxone-induced elevations in serum luteinizing hormone Neuroendocrinology 35 309-312

Cicero TJ, Schmoeker PF, Meyer ED, Miller BT, Bell RD, Cytron SM and Brown CC (1986) Ontogeny of the opioid-mediated control of reproductive 
endocrinology in the female rat Joumal of Pharmacology and Experimental Therapeutics 236 627-633

Cook SJ, Rawlings NC and Kennedy RI (1982) Quantitation of six androgens by combined high performance liquid chromatography and radioimmunoassay Steroids 40 369-379

Currie WD and Rawlings NC (1989) Fluctuations in responsiveness of LH and lack of responsiveness of FSH to prolonged infusion of morphine and naloxone in the ewe Joumal of Reproduction and Fertility 86 359-366

Curtis SK and Amann RP (1981) Testicular development and establishment of spermatogenesis in Holstein bulls Journal of Animal Science 53 1645-1657

D'Occhio MJ, Schanbacher BD and Kinder JE (1983) Androgenic and oestrogenic steroid participation in feedback control of luteinizing hormone secretion in male sheep Acta Endocrinologica 102 499-504

Donovan BT and van der Werff ten Bosch (1965) Definition of Puberty. In Physiology of Puberty pp 1-4. Edward Arnold, London

Ebling FJP and Lincoln GA (1985) Endogenous opioids and the control of seasonal LH secretion in Soay rams Journal of Endocrinology 107 34 1-353

Evans ACO, Currie WD and Rawlings NC (1992) The effects of naloxone on circulating gonadotrophin concentrations in the prepubertal heifer Journal of Reproduction and Fertility $96847-855$

Hahn J, Foote RH and Seidel GE (1969) Testicular growth and related sperm output in dairy bulls Journal of Animal Science 29 41-47

Joseph IBJK, Currie WD and Rawlings NC (1992) Effects of time after ovariectomy, season and oestradiol on luteinizing hormone and folliclestimulating hormone secretion in ovariectomized ewes Joumal of Reproduction and Fertility $94511-523$

Karg H, Giménez T, Hartl M, Hoffmann B, Schallenberger E and Schams D (1976) Testosterone, luteinizing hormone (LH) and follicle stimulating hormone $(\mathrm{FSH})$ in peripheral plasma of bulls: levels from birth through puberty and short term variations Zebtralblatt für Veterinärmedizin A23 793-803

Kennedy RI and Rawlings NC (1984) Administration of constant low doses of androgens to steers by silastic implant Journal of Andrology 5 87-92

Killian GJ and Amann RP (1972) Reproductive capacity of dairy bulls. IX. Changes in reproductive organ weights and semen characteristics of Holstein bulls during the first thirty weeks after puberty Journal of Dairy Science $\mathbf{5 5}$ $1631-1635$

Lacroix A and Pelletier J (1979) $\mathrm{LH}$ and testosterone release in developing bulls following LH-RH treatment. Effect of gonadectomy and chronic testosterone pretreatment Acta Endocrinologica 91 719-729

Limonta P, Maggi R, Dondi D, Martini L and Piva F (1987) Gonadal steroid modulation of brain opioid systems Journal of Steroid Biochemistry 27 691-698

Lunstra DD, Ford JJ and Echternkamp SE (1978) Puberty in beef bulls: hormone concentrations, growth, testicular development, sperm production and sexual aggressiveness in bulls of different breeds Joumal of Animal Science 46 1054-1062

McCarthy MS, Hafs HD and Convey EM (1979) Serum hormone patterns associated with growth and sexual development in bulls Joumal of Animal Science $491012-1020$

MacDonald RD, Peters JL and Deaver DR (1990) Effect of naloxone on the secretion of LH in infantile and prepubertal Holstein bull calves Joumal of Reproduction and Fertility 89 51-57

Merriam GR and Wachter KW (1982) Algorithms for the study of episodic hormone secretion American Joumal of Physiology 243 E310-E318

Peck DD, Thompson FN, Stuedemann JA, Leshin LS and Kiser TE (1988) Evidence for endogenous opioid modulation of serum luteinizing hormone and prolactin in the steer Joumal of Animal Science 66 3197-3201
Rawlings NC and Churchill IJ (1990) Effect of naloxone on gonadotrophin secretion at various stages of development in the ewe lamb Journal of Reproduction and Fertility 89 503-509

Rawlings NC and Cook SJ (1986) Plasma concentrations of testosterone, androstenedione, dihydrotestosterone, $5 \alpha$-androst-ane-3 $\alpha, 17 \beta$-diol, $5 \alpha$ androstane$3 \beta, 17 \beta$-diol and androsterone in bull calves: response to hCG Canadian Journal of Animal Science 66 975-982

Rawlings NC, Hafs HD and Swanson LV (1972) Testicular and blood plasma androgens in Holstein bulls from birth through puberty Journal of Animal Science 34 435-440

Rawlings NC, Fletcher PW, Henricks DM and Hill JR (1978) Plasma luteinizing hormone (LH) and testosterone levels during sexual maturation in beef bull calves Biology of Reproduction 19 1108-1112

Rawlings NC, Jeffcoate IA and Reiger DL (1984) The influence of estradiol-17 $\beta$ and progesterone on peripheral serum concentrations of luteinizing hormone and follicle stimulating hormone on the ovariectomized ewe Theriogenology 22 473-488

Rawlings NC, Churchill IJ, Currie WD and Joseph IBJK (1991) Maturational changes in opioidergic control of luteinizing hormone and follicle-stimulating hormone in ram lambs Joumal of Reproduction and Fertility 93 1-7

Rodriguez RE and Wise ME (1989) Ontogeny of pulsatile secretion of gonadotrophin-releasing hormone in the bull calf during infantile and pubertal development Endocrinology 124 248-256

Schams D, Gome S, Schallenberger E, Reinhardt V and Claus R (1978) Relationship between short-term variations in $\mathrm{LH}, \mathrm{FSH}$, prolactin and testosterone in peripheral plasma of prepubertal bulls Journal of Reproduction and Fertility 54 145-148

Schams D, Schallenberger E, Gome S and Karg H (1981) Endocrine patterns associated with puberty in male and female cattle Journal of Reproduction and Fertility Supplement $30103-110$

Schanbacher BD (1984) Pituitary testicular responses of estradiol-17 $\beta$-implanted bull calves to continuous versus pulsatile infusion of luteinizing hormone releasing hormone Journal of Animal Science 58 943-948

Schanbacher BD (1985) Endogenous opiates and the hypothalamic-pituitarygonadal axis in male sheep Domestic Animal Endocrinology 2 67-75

Schanbacher BD, D'Occhio MJ and Gettys TW (1983) Pulsatile luteinizing hormone secretion in the castrate male bovine: effects of testosterone or oestradiol replacement therapy Journal of Animal Science 56 132-138

Schulz R, Wilhelm A, Pirke KM and Herz A (1982) Regulation of luteinizing hormone secretion in prepubertal male and female rats Life Sciences 31 2167-2170

Secchiari P, Martorana F, Pellegrini S and Luisi M (1976) Variations of plasma testosterone in developing Friesian bulls Journal of Animal Science 42 405-409

Sirinathsinghji DJS, Motta $M$ and Martini L (1985) Induction of precocious puberty in the female rat after chronic naloxone administration during the neonatal period; the opiate 'brake' on puberty gonadotrophin secretion Journal of Endocrinology 104 299-307

Trudeau V, Pharazyn A, Beltranena E and Aherne FX (1990) Naloxone elevates plasma follicle stimulating hormone but not luteinizing hormone levels in the immature male pig Canadian Joumal of Animal Science 69 1095-1098

Wilkinson $M$ and Landymore $K M$ (1989) Do brain opioid peptides regulate the onset of puberty? In Brain Opioid Systems in Reproduction pp 70-94 Ed. RG Dyer and RJ Bicknell. Oxford University Press, Oxford

Wolf FR, Almquist JO and Hale EB (1965) Prepubertal behaviour and pubertal characteristics of beef bulls on a high nutrition allowance Journal of Animal Science 24 761-765 